\title{
Economic Growth and Human Capital
}

\author{
Mr. Shaikh Matin Shaikh Husen \\ Assistant Professor, Kohinoor College of Arts, \\ Science and Commerce, Khuldabad, Aurangabad, Maharashtra, India
}

\begin{abstract}
How to cite this paper: Mr. Shaikh Matin Shaikh Husen "Economic Growth and Human Capital" Published in International Journal of Trend in Scientific Research and Development (ijtsrd), ISSN: 24566470, Volume-3 | Issue-4, June 2019, pp.190-192, URL: https://www.ijtsrd.c om/papers/ijtsrd23 628.pdf

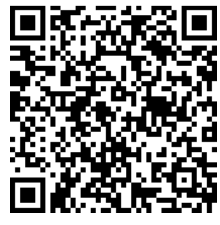
IITSRD23628
\end{abstract}

Copyright (C) 2019 by author(s) and International Journal of Trend in Scientific Research and Development Journal. This is an Open Access article distributed under the terms of the Creative Commons

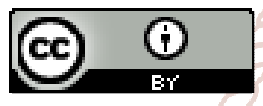
Attribution License (CC BY 4.0) (http://creativecommons.org/licenses/ by $/ 4.0$ )

There are, however, several areas of concern. Let me enumerate a few. The growth of agriculture in the last two decades has been slow. It has grown at the rate of two to four per cent since the 1980s and the area under cereals has remained almost stagnant for the last decade and a half. While primary sector contributes more than 20 per cent to the overall economy, it has provided nearly 60 per cent employment. The contribution of agriculture to the economy has gone up more than four times in the last five decades. The income of agriculture worker, however, has gone up only by about 75 per cent. This is due to our inability to reduce the dependence of working force in agriculture significantly by producing non-farm employment. Nearly half of those who are engaged in agriculture are not literate and a very small percentage has completed $10+2$ education. The size of holdings is getting small as these get more fragmented. The terms of trade in the last ten years have grown adverse, though there were some positive movements earlier. The nation today needs large inputs of technology in agriculture and, in particular, in major cereals like wheat, rice and pulses and oilseeds for improving productivity.

Availability of these basic goods in the market has to grow if we have to provide to our consumers food at reasonable prices. A major step up in investments in agriculture and technology will be required in the next few years. This should strengthen our ability to meet the growing requirements. It would help if we are also successful in creating more jobs in the manufacturing and informal sectors to improve incomes of those employed in agriculture.
Our nation today faces a number of challenges. One of the most important tasks before us is to improve standards of living, provide nutrition, education and health care to all our people and plan for high level of physical quality of life. This is a daunting task on which while successive Plans have made attempts, yet the progress has not been commensurate with our expectations. In the last one decade, we have made efforts to reduce the number of those people whose incomes are less than a certain minimum which is referred to as the poverty line. While in percentage terms, a measure of success has been achieved-there is an improvement of nearly five per cent-because of the increasing population, the actual number of people still below the poverty line remains around 30 crore. Our growth process has to be inclusive and must take care of these deprived segments of the population, while income inequalities exist; they are particularly glaring in certain states when measured against the national average. Over a period of years, the divergence amongst the states is growing wider, while 10 years back, the ratio between the lowest and the highest income states was 0.3 , it has deteriorated now to 0.2 . This means that the per capita income, which is the lowest Income, is roughly $1 / 5^{\text {th }}$ of the highest income level state of the country. This is not a very happy development. The growth process has to take care of this issue. In particular access to health care and education for scheduled tribes, scheduled castes, certain minority groups, and other low income groups are critical national needs. An inclusive growth can only mean that all are able to avail of these facilities for quality education and health care. 
This is a task which we have to address ourselves in right earnest. Development of human capital will be vital for rapid growth of these states and social groups.

As we plan for the next four decades and hope to take the Indian economy forward, make rapid strides, and join the World leaders-a key determinant will be the development of national human capital. While our country has mineral resources including deposits of coal and iron ore, considering the size of the growing population, these are quite inadequate. Any growth strategy has to be based on development of the human capital promoting excellence and improving productivity. A strong focus on improvement in quality and technology will be required in the coming years.

Nations progress when their human capital is strong. Japan is a shining example of this principle. It's more than 40 per cent; industrial plants and infrastructure were destroyed in the war. It made strong recovery and clocked very high rates of growth throughout the 1970s and the 80s. It developed a highly skilled and dedicated labour force which had a strong support from the educational system. It emphasised, apart from literacy, discipline, hard work and wage increases related to productivity. Increased savings, quality of investments, access to market and policy interventions which were consistent with the world economy were also important factors in its growth. It cannot be denied that a nation which had very little of its own mineral resources and raw materials was able to grow at such a fast pace, primarily because of a strong human capital base.

With a large working population entering this century, their employability will be improved only if skill levels are high. It is important that the skill levels are matching the demand of the economy. The pool of trained manpower and its competencies should meet the requirements of the industry. In particular, they should be globally competitive. A strong interaction with private industry which is a key driver of growth is vital for developing appropriate skill sets and capacities. A major skill development programme is planned by central government in the coining five years. Effective implementation of this would be important for the country's growth.

The BRIGS Report prepared by Goldman and Sachs has visualized a rapid growth of the Indian economy. One of our major strengths is the growing Working population and low dependency. In the western countries, people are living longer and the share of the working population is declining with increasing stress and old age. In the Indian economy, we have a better situation. This endowment, however, cannot be utilized unless we take comprehensive steps to improve literacy levels, develop skill sets, meet the gaps in research and development, improve investments in research and ensure that the access to various facilities is widespread and extensive so that all income groups can be benefitted by it.

A large number of young students today do not go to the universities. As against the World average of 21 per cent, only per cent of the young Indian students join the university stream for higher learning even for increasing it to 15 per cent which is planned in the next five years, major expansion in higher education infrastructure is required. There is a need for new world class Institutes and improving the quality of education. This requires investments in the libraries, laboratories, connectivity and other facilities of existing universities. Several new universities, polytechnics and colleges will have to be opened and capacities of existing institutions augmented. An expansion of this dimension would require, apart from investments, extensive planning. There is also the question of commercialization of education. A large number of engineering and management institutes have been opened in the private sector The educational facilities with several of these are very poor, Even though the regulatory bodies have made efforts in this direction, the situation continues to be depressing. Government would, therefore, have to play a major role by way of setting up new institutes, providing strong regulatory norms, developing self-regulation mechanisms and insisting on good infrastructure.

One of the main areas of concern in the higher education system is the declining number of students in natural sciences. The investments in technology and science determine the strength of a nation. Unfortunately, young boys and girls have recently preferred to shy away from the study of natural sciences. The number of research papers published in this field is limited and the research facilities are not expanding adequately. While some initiatives are planned to meet the gap by giving larger number of scholarships, there is a need to have a more comprehensive programme and larger funds, earmarked for this. If we can build a big and strong base of technology, the coming generation will see a very large body of young men and women trained in 'natural sciences', capable of undertaking fundamental research and thereby, improving the nation's technological capability.

A key determinant of human capital in the field of higher education will be the strategy for improving access and promoting excellence. The Knowledge Commission has made a strong case for expansion of open and distance education. It has in its recent report emphasized the potential of faster expansion of open and distance education. In this context, some of the suggestions which are worth considering relate to development of network of open and distance education institutions, setting up of a National Education Foundation for developing common open resources and facilitating convergence with conventional universities.

To enable a quick assessment, one of the important suggestions is setting up of a national testing service. In some other areas requiring improvement in the quality of education and for meeting the gaps in faster expansion, it has recommended setting up a research foundation to support research activity and overhaul of the training programme of the educators, development of a system for quality assessment, developing production of quality content through selected set of Indian institutions, leveraging of global educational resources and creating faculty and institutional development programmes. All these suggestions and several others are aimed at expansion and quality improvement on a long-term basis of the open education and distance learning systems.

Expansion of higher education to cover about 15 per cent of the 18 to 23 years age group planned in the next five years will require major expansion of faculty. In a short time, this will be extremely difficult. It will be particularly so in the field of medicine, management, engineering and other new disciplines. The salary structure of young boys and girls coining out of the institutes in some of these disciplines is 
quite attractive in the private sector. This is particularly so in certain segments like IT. Teaching and research, therefore, do not attract bright students as a good career option when they come out of the university. This trend has to be reversed.

The problem in the field of higher and technical education has been further compounded by the nature of growth of institutions of higher learning. Till a decade back, private engineering and medical educational institutions in northern India were very few. With the coming of private investments in this sector, a very large number of management and technology institutes have come up. This sudden spurt in these colleges has given rise to a severe faculty shortage. It also has impact on the quality of teaching and the excellence in education which we are trying to promote. This is a serious issue. Open universities can take up the development of faculty and quality educational material in all seriousness.

As many of you complete your University education and go out to face the challenges of the career which you may have in mind and plan for realization of the vision and dreams which many of you will have, there will be several impediments and difficulties in your way. You would face them well if you have a commitment to quality and excellence. Sometimes you may also feel unclear in your mind as to which path to adopt. Often you may face difficult decisions where the ideals that you have with you and the reality of life are widely different. These tough times will be your real test. I hope that when such occasions arise, you will stand by what is right, fair and just and promotes excellence. It is this ability and adherence to principles which in the long run will take you far. It is your dedication and commitment to your ideals which will shape your future life. Sometimes you may be tempted to give up your ideals for immediate gains. Such victories occasioned by these temptations would definitely be short-lived and may cause you incalculable harm in the long run.

\section{Reference}

[1]. Aggarwal, A. (2000). Web - Based Learning and Teaching Technologies: Opportunities and Challenges. Hershey PA: Idea Group Publishing.

[2]. Aggarwal, Binod C. (2005). Educational Media in India, Perspectives on District Education Educational Media in Asia , Commonwealth of Learning, Vancouver , BC, Canada,

[3]. Anjanappa, K (1988). Mutual for Coordinators of Study Centres, IGNOU publication, New Delhi.

[4]. Bates, A.W., (1990) Interaction as a criterion for media selection in distance education, Interactive Communication in Distance education (AAOU, 1990 Annual Conference Papers), Jakarta.

[5]. Bates, A.W. (1995). Technology , Open Learning and Distance Education, Routledge London,

[6]. Cann, A.J. (2000). On-Line Interactive Computer Assisted Learning. Retrieved on from http://horizon.unc.edu/projects/monograph/CD/Prof essional Schools/Cann.asp

[7]. Chaudhari, M.M. (1997). The Limits and Challenges of Educational Technology in the Paradigm of Sustainable Development of India. In Educational Technology 2000; A Global Vision for Open and Distance Learning (conference papers), Singapore (August 15-17) (1996), The Commonwealth of Learning, Vancouver, BC, Canada,

[8]. Marian, Croft (ed.) (1991). Report on Round Table on Student Support Services. The Commonwealth of Learning, Vancouver, BC, Canada.

[9]. Keegan, Desmond (2002). Globalisation of Distance Learning; Challenges in the New Millennium towards Virtualization, Open and Distance Learning, Kogan page India Private Limited, New Delhi. 